\title{
Racism, Hispanidad and social hierarchy in medical- psychiatric thought during early Francoism. The work by Misael Bañuelos (1936-1941)
}

\author{
Ricardo Campos \\ Departamento de Historia de la Ciencia. \\ Instituto de Historia, CSIC \\ e-mail: ricardo.campos@cchs.csic.es \\ ORCID iD: https://orcid.org/0000-0002-1098-3616
}

Submitted: 1 April 2020. Accepted: 1 September 2020.

\begin{abstract}
A range of discourse and racial proposals are analyzed and confronted in the article that were pursued from within Medicine and Psychiatry during early Francoism. In particular, Misael Bañuelo's openly biologistic vision that was influenced by the racial theories put forward by Nazism are discussed. His confrontation with the racial conception sustained by followers of Hispanidad (Spanishness) and National Catholicism are analyzed, especially that with Vallejo Nágera.
\end{abstract}

KEYWORDS: Racism; Social hygiene; National Catholicism; Nazism; Medicine.

Citation / Cómo citar este artículo: Campos, Ricardo (2021) "Racism, Hispanidad and social hierarchy in medical-psychiatric thought during early Francoism. The work by Misael Bañuelos (1936-1941)". Culture \& History Digital Journal, 10 (1): e006. https://doi.org/10.3989/chdj.2021.006

RESUMEN: Racismo, hispanidad y jerarquía social en el pensamiento médico-psiquiátrico del primer franquismo. La obra de Misael Bañuelos (1936-1941).- En el artículo se analizan y confrontan diversos discursos y propuestas raciales que se dieron en el seno de la medicina y la psiquiatría del primer franquismo. En especial se aborda la visión de Misael Bañuelos, abiertamente biologicista e influidas por las teorías raciales del nazismo. Se analiza también su enfrentamiento con la concepción racial sostenida por los partidarios de la Hispanidad y del Nacionalcatolicismo, en especial con Vallejo Nágera.

PALABRAS CLAVE: Racismo; Higiene racial; Nacionalcatolicismo; Nazismo; Medicina.

Copyright: () 2021 CSIC. This is an open-access article distributed under the terms of the Creative Commons Attribution 4.0 International (CC BY 4.0) License. 


\section{INTRODUCTION}

In 1941, the Medical Pathology chair at the University of Valladolid, Misael Bañuelos, claimed that:

The image of the Spanish people has been tarnished and bastardized for many centuries, and they continue crossbreeding with the inferior races who contribute to our land (...) This amounts to suicide in inferior races. I read of a famous Spanish writer taking pride in the fact that Spain had eliminated Germanic influence, which had been spread by the Visigoths. And he celebrates this fact, even though it was necessary for us to be invaded by the peoples of North Africa-Arabs, Berbers and negroes, etc.(...) Conversely, I feel proud to have at least six eighths of Nordic Germanic blood, from the finest Aryan stock" (Bañuelos, 1941a, pp. 60-61).

These words, to be found in his book Temas y meditaciones breves ('Brief themes and meditations'), clashed full-on with most texts about racial issues arising from the political and scientific sphere of activity during Francoism. Broadly speaking, they defended a racial conception based on crossbreeding. Ramiro de Maeztu had maintained "that race (...) is made up of speech and faith, which translates into spirit rather than protoplasmic obscurities", first in 1932 in the journal Acción Española ('Spanish Action') and later in his 1934 work Defensa de la Hispanidad ('In Defense of Spanishness') (Maeztu, 1934, p. 70). His postulates therefore allowed for all "white, black, Indian, Malayan and mestizo" people who spoke Spanish and were Catholic to be integrated into a single community (Maeztu, 1934, p. 69). Hispanidad was the key concept that enabled an apparently universalistic and Catholic racial conception to be articulated (Morodo, 1985; Villacañas, 2000, pp. 379-411). This did not refer to a specific land or race, but rather, to a linguistic and religious spiritual community that brought together an entire people. In keeping with these ideas, the psychiatrist Antonio Vallejo Nágera, who was also a partner of Acción Española, developed a series of racial and eugenic ideas during the 1930s and 1940s that connected with those put forward by Maeztu. Thus, in 1937 in Eugenesia de la Hispanidad ('The Eugenics of Spanishness') he applied his eugenic premises to the concept of Hispanidad by putting together a contradictory racial theory that explicitly avoided a biological definition of race. Conversely, he proposed another theory based on the existence of a spiritual and cultural community existing between Spain and the Americas revolving around language, Catholicism, habits and culture (Vallejo Nágera, 1937). The racial fusion message as a core idea was repeated in different versions discourse of the Spanish far right in the 1930s. Even the openly Fascist Giménez Caballero (Saz Campos, 2003, pp. 105-118; Selva, 2004, pp. 69-108) also insisted on this idea in his book Genio de España ('Genius of Spain'), published in 1932. In this regard, Goode $(2009$, p. 3$)$ pointed out that the leaders of the far right and Spanish Fascism would have denied the existence of racism within their organi- zations, highlighting the fact that their racial conceptions supported crossbreeding as a key factor in them and that they distanced themselves from what was being proposed by Nazism. According to this author, historiography approached European racial policies "through the lens of the Nazi regime", which entailed a lack of interest in Spanish racial ideas because they failed to fit in with the notion of racial purity "espoused by the Nazi German model" (Goode, 2009). Something similar occurs in another field that is closely linked to racial considerations: that of the history of eugenics. The Anglo-Saxon model is taken as a reference, being deemed negative, biologistic, coercive and interventionist in terms of bodies, insofar as other versions of eugenics, such as those developed in Latin America or Spain, are confined to mere references to social hygiene within a marked Catholic, environmentalist approach (Stepan, 1991; Álvarez, 2007). However, these types of approach have recently been qualified, showing, not without controversy, how the alleged notion of Catholic, environmentalist - in short, Latin - eugenics would have exerted moral coercion over the population (Miranda, 2003; Vallejo and Miranda, 2014) or even left the possibility open for intervention in the bodies of criminals through sterilization (Campos, 2018).

Therefore, within a context mainly inclined towards racial crossbreeding, Bañuelo's words sound unorthodox, although his vehement rejection of racial fusion should not be sidestepped or played down by considering it as a mere anecdote or a marginal, even picturesque stance. Firstly, this is because his thoughts on the subject originated from back further in time. Between 1936 and 1938, he amply expounded his political and racial thought in the six volumes that made up his work Problemas de mi tiempo y de mi patria ('Problems of my Time and my Fatherland'). As suggested in the prologue to the first volume, his aim was to explain the reality of the situation "regarding the political and historical problems" faced by Spain from a biologist's standpoint (Bañuelos, 1936, p. 5). This supposedly scientific and neutral standpoint, based on the observation of facts, focused on an analysis of social, political and economic problems in racial terms that were very close to the theses being put forward by Nazism via Darwinian social and biologistic stances - stances that he studied in depth in 1941 in his book Antropología actual de los españoles ('A Current Anthropology of the Spanish'), in which the following was openly stated:

Since the time of Hitler's rise to the helm of that great country, it is the State in which notions of racial hygiene have been developed the most, this has been translated into a great deal of legislation aimed at protecting their race and encouraging it to be improved and purity maintained.

Such conceptions could only be arrived at by taking the exact standpoint that not all races are the same- not only in terms of their physical features, but also in their intellectual and moral worth and in their creative and organizational strength (Bañuelos, 1941b, p.12). 
Secondly, Bañuelos did not publish his writings from a marginal stance. He held the Medical Pathology chair when he wrote his racial work, prior to which he had been Vice-Rector and Rector of the University of Valladolid (1929-1931) and Dean of the Faculty of Medicine between 1931 and 1934. From 1945 onwards until his death in 1954, he was Honorary Advisor of the CSIC (Spanish National Research Council) and director of the Section of the Bernardino de Sahagún Institute that this same organization opened in Valladolid. ${ }^{1}$ Thirdly, there were numerous scientists and thinkers on the Francoist side who maintained stances that fluctuated between admiration for Hitler and the fostering of the racial hygiene policies pursued by National Socialism, and the rejection of the most stringent, negative eugenic measures pursued by Nazism (Saz Campo, 2003; Gallego, 2014). There were also sectors among the falangists-especially at the core of the journal Escorial - that expressed their admiration for the Axis and for National Socialist Germany and defended military backing for the "New Order" cause.

Fourthly, the relevance of intellectual debates regarding the weight and importance of the German element in Spanish history and culture should also be taken into consideration as a factor in the strength or decline of the country (Goode, 2009). Owing to its major cultural influence during the period subject to study, one of the most important examples was the debate embarked on in Invertebrate Spain by Ortega y Gasset (1922), in which he pointed to the fact that the weakness of the German element in Spanish history, represented by the low racial quality of the Visigoths, suggested the lesser vitality of Spaniards (Elorza, 1984). Ten years later in Genio de España, Giménez Caballero fiercely replicated the "blond thesis [tesis rubia]" put forward by Ortega. In other fields such as Archaeology and Anthropology, the Aryan interpretation of Spanish prehistory and ancient history by Julio Martínez Santa-Olalla, well-known for having acted as Himmler's guide on the latter's visit to Spain in 1940 and for his unapologetic sympathy for Nazism, represents a further example of the cultural undercurrent evident at the time and of the regime's ambiguity towards Nazi postulates (Díaz-Andreu, 2002, pp. 80-120; Mederos Martín, 2003-2004; Wulff, 2003; Tomás Cardoso, 2015).

Historiography has shown a striking indifference to the social and racial biological facet of Bañuelos's work. The contrast between the amount of work about Vallejo Nágera and relative silence with regard to Bañuelos is a surprising one, despite the existence of the latter's work being known. Approaches taken from within the History of Science have been practically non-existent and confined to some general mentions without going into any great depth (Álvarez, 1998; Polo, 2006; Cayuela, 2014; Campos, 2016). We also find two biographies written by doctors who either ignored (López Sáez, 1983) or largely and uncomfortably overlooked (Granda, 1987) the racial biological work undertaken by Bañuelos. Lastly, there is additionally some approach of interest to his view of gypsies within the framework of works that are more broadly linked to scientific discourse about this social group (Rothea, 2007, 2014).
Conversely, there has tended to be considerably greater interest in Bañuelos from the standpoint of Political History. His role as a driving force behind Castile's autonomy during the Second Republic and the drafting of some basic requirements for it in May 1936 are the reasons for the closer attention paid to this (Blanco, 1997; Palacios, 2015; Guinaldo, 2015). The racial theme is alluded to in some of these works, mainly focusing on his characterization of the Castilian race but playing down the importance of or overlooking his link to German racial thought (Guinaldo, 2015, pp. 1143-1144).

Special mention should be made of the republishing in 2007 of his work Antropología actual de los españoles ('Current Anthropology of the Spanish') with the title slightly changed to Antropología de los españoles ('Anthropology of the Spanish') (Bañuelos, 2007). This edition includes an introduction and series of explanatory notes about Bañuelos's work which, apart from praising and adopting his thought, also criticizes the disappearance of racial anthropology as a consequence of the "inquisitional focus and censorship by the Academy of right-thinking". The use of Nazi or Neo-Nazi authors as bibliographical back-up is also well-known in the above-mentioned notes, as is the change in images from the original work and restructuring of the index (Bañuelos, 2007).

This article is an initial approach to the racial political thought of Bañuelos. An attempt is made to present the main lines of his thought in this field between 1936 and 1941 by showing its peculiarities in contrast to the predominant tendencies of the day. To this end, the six volumes that make up the work Problemas de mi tiempo y de mi patria (1936-1938), Antropología actual de los españoles and Temas y meditaciones breves are analyzed, the last two mentioned dating from 1941. The analysis is confined to certain aspects of his work such as his racial political views about Spain, his notion of decline, the hierarchization of races, his rejection of Hispanidad, racial aspects of his thought on the political role of Castile and his proposals for racial improvement policies.

\section{THE RACIAL THOUGHT OF BAÑUELOS: A DIS- RUPTIVE WORK?}

During the first few months of the Spanish Civil War, Bañuelos published the first volume of his work Problemas de mi tiempo y de mi patria, which bore the subtitle Cuestiones político-biológicas ('Political-Biological Questions') (1936). A further five tomes would see the light of day over the following two years, bearing subtitles according to the subject matter being dealt with: Revoluciones políticas y selección humana ('Political Revolutions and Human Selection') (1937a), Universidad, prestigio y grandeza nacional ('University, Prestige and National Grandeur') (1937b); Mentalidad y progreso humano ('Mentality and Human Progress') (1937c); Temas de crítica diaria ('Themes of Daily Criticism') (1938a) and Los grandes errores nacionales ('Great National Mistakes') (1938b). Although these were published over a short time span, the main title was shared between 
them and they covered all issues from a biological and racial standpoint, and they did not constitute a previously designed outcome. If we are to believe Bañuelos, the work was a mix of previously written material and other, newly drafted texts. Thus, the first volume mainly gathered together a set of lectures given between 1933 and 1935 that had been previously published in El Norte de Castilla, whereas the second comprised a further series of "hitherto unpublished works and other writings from the time" (Bañuelos, 1937a, p. 7). The outbreak of the Spanish Civil War would have spurred him on to publish his thoughts with a view to broaching in his own words a series of problems from a non-scientific, simple and comprehensible standpoint with which, in his opinion, Spain was burdened at the time - and the solution to which, far from lying in political sectarianism, might pave the way for national resurgence and recovery of its standing among powers.

The intention of helping to solve the country's problems via a biologistic, racist and eugenic approach, as well as his concern with ensuring his thoughts reached a wider public, places his work on a level of that of the biocratic $^{2}$ essays by the French psychiatric, Edouard Toulouse (Huteau, 2002; Campos, 2007), and the best seller L'homme c'est inconnu ('Man, the Unknown') (1935) by Alexis Carrel, published simultaneously in French and English (Drouard, 1995; Regianni, 2006). In the case of Spain, the writings by Vallejo Nágera, with some nuances, could be said to form part of this universe. Albeit with some differences, these authors analyzed the problems facing their societies in supposedly scientific and neutral terms, placing social and eugenic medical care at the center of their solutions. Generally speaking, they considered a new social hierarchization that went beyond economic factors and was based on the elevation of the most gifted from a biological, psychological and spiritual standpoint. Openly anti-liberal and anti-parliamentarian, these works rejected democracy and its social equality policies as it fostered the rise of the mediocre to positions of responsibility. They also expressed fears and anxiety raised by the new society of the masses and shared the sense of Western decline felt by much of the European intellectual and cultural world. Within such an amalgam of discontent, scientific proposals emerged as an aseptic tool that would be capable of equipping policy with the content of good government. However, in most cases, a strong sense of nationalism and sympathy towards farright schools of thought remained hidden, except in the case of Toulouse, who was on the left, albeit in favor of a government and parliament made up of scientists. These works transformed socio-economic inequalities into differences in biological and psychological capacities, pushing structural economic causes that favored social differences into the background. In the case of Spain, the works covering these types of issue may be considered combat writings in the service of the Francoist cause (Casco Solís, 1999). Thus, works by Vallejo Nágera about race, eugenics and madness and war, lectures by López Ibor at the University of Salamanca (López Ibor, 1938) and, somewhat later, about the neurosis of war (López Ibor, 1942), or those by Francisco Marco about mental hygiene (Marco Merenciano, 1958 [1942]), among other things shared a rejection of democracy and served the purpose of demonstrating the biological, psychological and moral inferiority of the Republicans. The work by Bañuelos fits into this category although, as has been pointed out, the main feature of his works was his biological reductionism, his openly racist discourse and his admiration for Hitler. This clashed to a certain extent with that of other scientists from the rebel side who were far more influenced by Catholicism and maintained an openly racial perspective that defended crossbreeding.

\section{RACE, POLITICS AND SOCIAL HIERARCHY}

Racial issues revolved around and gave meaning to Bañuelos's biological view about the political, social and economic problems facing Spain and the Western world. Our doctor declared himself to be in favor of racism as a political option:

Racism has been the most fruitful and revolutionary biological conception of recent times. And, despite the repulsion with which it has been received in nearly all Spanish intellectual media, who are poorly prepared for racist doctrine, it is clear and undeniable that for the biologist it represents the greatest advance made in political science in recent times (Bañuelos, 1936, p. 69).

His praising of biological racism overlapped with the political analysis of the situation in Spain and Europe in the 1930s. Throughout the six volumes of Problemas de mi tiempo, he would insist on the "close relationship existing between Biology and Politics in paving the way for the improvement of a people and a race" (Bañuelos, 1936, p. 127). His work was sprinkled with praise for National Socialism and Hitler, who he considered the "man with the most brilliant common sense among those governing peoples in modern times" (Bañuelos, 1937c, p. 152) and a politician prototype for having viewed Germany's problems as a racial people, rather than just a Nation and State (Bañuelos 1938a, p. 63). From the example of the German dictator, he also maintained that, far from "serving a State and a Nation", politicians should be "leaders of a people". To this end, they needed to have "a biological concept of politics" (Bañuelos, 1938a, p. 65) that would translate into "the racial cultivation of a people" with a view to improving the nation (1938a, p. 117). Yet his racism was also founded on his reading of openly pro-Nazi psychologists, educators, doctors, geneticists and psychiatrists who cultivated eugenics and raciology, such as Fritz Lenz, Wilhelm Hartnacke, Bruno Petermann, Alfred Ploetz, Ludwig F. Claussen, Friedrich Keiter, Frit Kern and Hans Friedrich Karl Günther, among others ${ }^{3}$.

With this baggage in tow, Bañuelos tackled the issue of the Spanish "reality" from a racial standpoint, by tracing the psychological and somatic features of the different races which, in his view, made up the Spanish population. 
In Problemas de mi tiempo, he dealt with this issue in a rather unmethodological manner, with merely classificatory considerations and racial hierarchy being interspersed with racial biological interpretations of Spanish history. Conversely, in Antropología actual de los españoles, he structured his work better by dividing it into 21 chapters. The first two focused on general issues and on a definition of race, while the following 12 were devoted to the specific study of the races that populated Europe and Spain, who he quantified into ten groups: Nordic, Mediterranean, Dalic ${ }^{4}$, Dinaric, Alpine, Pre-Asian ${ }^{5}$ Jewish people, Oriental, from south-eastern Europe and gypsy. The final chapters focused on a range of issues such as territorial distribution of racial groups, their role in Spanish history, racial mixes and their consequences, and current features of Spanish people.

Despite all these lucubrations, Bañuelos only defined race concisely in the chapter devoted to the concept of race in his book Antropología actual de los españoles:

A human race is, in reality, a group of humans that is clearly and accurately distinguished from other groups by its bodily features and by its psychic activities, and that when reproducing always produces human beings with identical bodily features as their parents, and with similar capacities and spiritual activities" (Bañuelos, 1941b, p. 17).

He defended the difference between nation, state and people via these postulates. The concept of people was a "racial, bloodline concept, a matter of stock", whereas those of "Nation and State" were political notions and their existence was not founded "in the blood of a race, nor in its spirit" (Bañuelos, 1938b, p. 25). And nor in common language, because race was a "biological concept about which the laws of men can do nothing" (Bañuelos, 1941b, p. 17).

Therefore, there is a palpable difference compared to Francoist scientists who concerned themselves with racial hygiene. Bañuelos openly wrote about the physical and psychological aspects of race, hierarchizing them, and is so doing established four basic races in Spain: Nordic, Mediterranean, Dalic and Cro-Magnon. These fitted in quite well in terms of their physical and psychological features, whereas the other races-Jewish, gypsy, PreAsian and Oriental-constituted a danger to the nation and had contributed to its decline.

Although no other Francoist scientist set out such detailed racial considerations, giving or taking some obvious differences, Vallejo Nágera also used similar mechanisms.

His peculiar interpretation of Kretschmer's biotypology (Álvarez, 1998; Huertas, 1996) revealed a close bond between physical and psychic attributes that was also capable, in its coarser version, of giving rise to biotypology hierarchies in which certain individuals would have constitutions and temperaments deemed superior to others. During the Spanish Civil War, biotypology proved very useful in pathologizing Republicans, as demonstrated in his well-known works with members of the International Brigade and Spanish female political prisoner in concentration camps and prisons (Huertas, 1996; Bandrés and Llavona, 1997). In his book Biotipología ('Biotypology') published in 1947, Vallejo set aside the fifth chapter to racial biotypology. Although he stressed the importance of the environment in biological inheritance and maintained that works by Nicola Pende and Ernst Kretschmer correctly focused on racial studies, when he expounded the theory of "European psychotypology" he referred to Bañuelos as an authority with regard to some psychological features of race (Vallejo Nágera, 1947, pp. 125-132).

The importance of racial study to Bañuelos lies in the formulation of a radical biopolitical project in which $\mathrm{Eu}-$ ropean and Spanish history and social reality was interpreted exclusively in biological terms. Thus, attributing certain physical and psychological features to each race was reflected in specific political attitudes and so the class struggle in Spain was not because of unjust socio-economic organization, but rather, was sustained exclusively "by Eurasians of different varieties" who dragged individuals "from other racial other groups" (Bañuelos, 1936, p. 144). In this regard, Bañuelos was emphatic:

From trade union groups to traditionalists, political war is maintained between Eurasians in order to take possession of power, with the sole exception of some Dalic peoples and Cro-Magnon peoples, who are mostly found in parties on the right: the Cro-Magnon on the right and the Dalic peoples on the moderate right (Bañuelos, 1936, p. 136).

By way of an example, he maintained that individuals who had "created stronger political parties are the ones that have a great deal of Nordic blood, as was the case with Pablo Iglesias, and also with Largo Caballero" (1936, p. 136). In short, his thought could be summarized by the notion that preferences towards one or other political doctrines corresponded to "racial sympathy" (Bañuelos, 1937c, p. 124).

The rejection of Catalan and Basque separatism and Navarre's autonomy accounted for much of his political concerns. Against this, he defended Unitarianism and legislative and tax uniformity in order to build a strong and egalitarian nation. These stances were linked to the Castilian autonomism he defended during the Republic as a reaction against the Catalan Statute of Autonomy and approval of the equivalent Basque one, which led him to set out some requirements for a Castilian Statute of Autonomy in May 1936. As many authors have pointed out, his autonomism was instrumental and his aim was to ensure that Castile would not end up becoming subordinate to the interests and privileges that the Catalan Statute of Autonomy granted to Catalonia (Blanco, 1997, p. 96), although his firm defense of both regional and municipal autonomy would be conceived as a way of regenerating Castile (Blanco, 1997, p. 99). The outbreak of the Spanish Civil War meant abandoning these aspirations, closing ranks around Spanish nationalism. Bañuelos openly expressed opposition to any difference between regions. In his opin- 
ion, regionalist and autonomist tendencies were opposed to progress and would lead to "the weakening of the great States and to the dismembering of strong nations, with a return to medieval barbarism, and subsequently to savagery" (Bañuelos, 1937c, p. 151). His criticism extended to autonomism in Navarre, expressing his profound indignation about such stances (1937c, p. 154), and yet his political criticism also had a racial explanation. Thus, he thought that Castile, following several centuries of biological decline, needed a "racial-type hygiene cure" in order to recover the "genes of the Castilians" and give rise to the region's resurgence, to ensure they would "once again play a role in the life of the country akin to what they used to perform" (Bañuelos, 1936, pp. 76-77). Because the key to Spain's resurgence was Castile, from where the former had to be articulated. In this regard, Bañuelos established a connection with the school of thought that defended the bond between Spain and Castile and about which, from the late $19^{\text {th }}$ century onwards, much was written in an intense cultural debate in terms of the essence of fatherland (Morales Moya y Esteban de Vega, 2005). However, the desire for a uniform Spain operating under the same tax system had been cut short in 1521 with the defeat of Revolt of the Comuneros in Villalar, paving the way for the biological decline of Castile. The long-term biological consequences proved to be the limited naturalization of the people and the rise of separatism and autonomism that broke with unity and favored economic, fiscal and administrative privileges in some regions over others. This constituted "a biological crime and a slow crime" against the rest of the country. The only difference accepted at the nation's heart was a racial one, "as advocated by the German racists", involving a defense of the privilege of "multiplication of the best and obstacles to the worst" (1936, p. 17), as Spain's unity and uniformity needed to be built "on real and tangible basic principles", which are solely biological” (1936, p. 19).

\section{HISTORY AND DECLINE OF SPAIN: HISPANI- DAD IN QUESTION}

There was a proliferation of writings by doctors and psychiatrists in the 1930s and especially since the time of the Spanish Civil War who took reactionary or openly Fascist stances, reflecting on Spain's decline. Their main argument, which was in keeping with the ideological view of exacerbated nationalism, was the challenge facing the most recent centuries of Spanish history, which was in turn being interpreted as a long period of decline and a loss of national essence - owing to the gradual abandonment of Catholicism in favor of enlightened, liberal and Marxist ideas. The Republic represented the culmination of that historic degradation process and the growth of anti-Spanish ideas; as such, the military uprising of $18^{\text {th }}$ July 1936 would be the necessary turning point, the heroic starting point for embarking on the rebirth of the country and the recovery of its essence (Saz Campos, 2003; Gallego, 2014).

The racial question was omnipresent in the field of Francoist medicine. This advocated improving the charac- teristics and capacities, both physical and intellectual, of the Spanish people (Polo, 2006; Álvarez, 2007). Although the improvement of the race, impregnated since the end of the $19^{\text {th }}$ century to anthropology, psychiatry, medicine and criminology, now was raised in somewhat different terms.

Firstly, liberal and progressive perspectives of the issue were abandoned and fought against, as they were considered part of the "disaster" being experienced by the country (Goode, 2009). Instead, Catholicism inspired racial policies and defined race and national essences (Álvarez, 2007; Vázquez and Moreno, 1997; Cenarro, 2006; Campos 2016, 2018). In a complex appropriation and reinterpretation process it was intermingled with duly purged biological and psychosomatic issues. Secondly, the definition of Spanish racial essence in political and racial terms established by the "New Order" excluded a large part of the population, who remained tarnished with the common label of being anti-Spanish and, as such, needed to be eradicated from national life (Cayuela, 2014; Campos, 2016). In this regard, the works by Vallejo Nágera constituted the most complete proposal-both on a theoretical and practical level. His research into Republican prisoners of war "demonstrating" their psychological and mental inferiority and the proposal of punishment and re-education are a good example of this (Huertas, 1996; Bandrés and Llavona, 1997).

In 1937, he analyzed the causes of the decline of the Spanish people in Eugenesia de la Hispanidad and put forward a regenerating program. The ideological framework that the work fell within - the journal Acción Española - and its publication within the context of civil confrontation, reformulated the traditional discourse about the racial decline of the Spanish people that had hitherto pervaded. Vallejo Nágera pathologized the Republicans and all schools of thought deemed to be dissident, creating a favorable atmosphere for medical and eugenic intervention within the social milieu. His analyses and proposals, which were repeated in numerous works, constituted a biopolitical project in the service of the coup plotters and the Francoist New State. In this regard, he proposed unleashing "a bold hygiene struggle against the morbid germs undermining the Spanish race", which had favored "the out-of-control pursuit of instinctive tendencies" against the "God, Fatherland and Family" constellations embedded in the collective conscience of the people. Vallejo yearned for the society of the Ancien Régime and proposed strict social hierarchization and the reincorporation of the human values of the $15^{\text {th }}$ and $16^{\text {th }}$ centuries into people's thought, habits and conduct, with a view to morally restructuring the environment in such a way as to psychologically reinforce the phenotype to ensure it would not force the genotype into decline" (Vallejo Nágera, 1937, p. 109). Other psychiatrist and doctors such as López Ibor, Francisco Marco Merenciano, Pedro Camy and Alfonso de la Fuente Chaos shared his diagnosis about Spanish decline and also proposed the eradication of any anti-Spanish tendencies (Campos and Novella, 2017).

For his part, Bañuelos, although he shared a general admiration for the imperial glories of the $16^{\text {th }}$ century, 
nonetheless distanced himself both from any analysis of its meaning in terms of the historic process of Spain's development or any interpretation of the country's decline. His antagonism towards the reactionary or Catholic stances of his medical colleagues to a certain extent formed part of a greater dispute between sectors of the regime close to Acción Española and to the traditionalism of the falangist supporters. Saz Campos (2003, p. 164) had shown how the Unification Decree of April 1937 had the effect that different forms of nationalism on the Francoist side joined forces "in an unstable truce characterized by the existence of shared territories that were, at the same time, considered territories in dispute. According to this author, unification had transformed them all into "fascists and imperialists, traditionalists and Catholics" (2003, p.164), although interpretations of each differed markedly despite having points in common. It is within that general framework in which Bañuelos's disagreements with and proposals for a sense of Spanish history can be best understood, along with his notion of decline and his resurgence proposals, especially that referring to empire. Having said this, his substantial differences of opinion with Acción Española cannot be interpreted mechanically as full identification with falangist stances. Although his work is sprinkled with praise for the falangists of Valladolid owing to their ability to change the course of history and coincides significantly in matters such as the notion of "empire" and the interpretation of the country's history and decline, Bañuelos's racial and biological obsession is an aspect that blurs full identification with them.

His major objection to Hispanidad and racial crossbreeding as elements that shaped the Spanish "race" clearly aimed at sectors close to Acción Española and, in particular, Vallejo Nágera, although he never mentioned this or received any response to his attacks from the latter. Far from being spiritual interpretations, he maintained that only unity with the "biological" aspect could act as a true gauge of the history of mankind, as this was an allout struggle for the survival of each racial group with a view to asserting themselves over others. That notion of history as a permanent battleground between races was clearly linked to the idea that "one people, one nationality, an empire and a culture or civilization" were the product of decisions or imposition "by a small number of individuals belonging to the same racial group". According to this idea, such a group would need to be equipped with an organization and leader to ensure the growth of that people, "expand borders" and "increase the wealth and material power of its inhabitants. The methods used to ensure that growth might involve collaboration with other "racial groups", their subjugation "where necessary", or extermination "if they offered resistance" (Bañuelos, 1936, p. 51). This conquest would be justified in biological terms: "the laws of growth and prosperity are imposed by nature in such a way that one has the will to be or not". If one has it, "all means put into practice" that were geared to ensuring this would be welcome as long as they brought success, conversely constituting ills if they led to failure (1936, p. 51).
However, within the ideological context of the Francoist conglomerate, one could well ask how this type of reasoning could be translated into an interpretation of Spanish history and its decline, and into how these biologistic and racist premises fitted into that conglomerate.

Bañuelos confined Spanish decline to racial decline, the fruits of decisions by the governing class and the spreading of internationalism in Spanish life. Unlike Vallejo Nágera, Acción Española, traditionalism and sectors of the falangists, Bañuelos did not seek to mystify the Golden Age as the climax of Spanish history. Opposing the idea that "so great was Spanish thought of the $16^{\text {th }}$ century, so solid was Spanish philosophy, so profound was the knowledge of apologist intellectuals that Spain was able to free itself from Protestantism and impiety for two centuries" (Vallejo Nágera, 1938a, p.153), Bañuelos openly criticized the House of Hapsburg. The reigns of Charles I and Philip II were "biological mistakes" (Bañuelos, 1938b, pp. 11-12) and a failure from the racial standpoint, because they did not defend "national ideals but royal conceptions and feelings" that did not translate into "greater progress and power of the nation" (1938b, p. 47). In this regard, he compared the spirit of Don Quixote with El Cid, pointing out that many military campaigns of the modern age "look for all the world like Don Quixote moments of madness rather than the courses of action taken by Rodrigo Díaz de Vivar". His spirit, he concluded, had not been "imitated following the deaths of Isabel I and Ferdinand V of Aragon" (Bañuelos, 1938b, p. 48). To the lack of national vision on the part of the Hapsburgs, racial crossbreeding was added as the specific biological cause of the decline. In this regard, he was of the view that "our colonial empire disintegrated like foam because racially mixing with the aborigines of each country, by crossing their blood" gave rise to the type of mestizo who did not feel Spanish (Bañuelos, 1938b, p. 50). On this point, Bañuelos expressed his total lack of conformity with the idea of Hispanidad, challenging its validity in a tone that was both coarse and racist:

If the Spaniards, wherever they happened to be at the time of the conquests, had kept their blood clean and not crossbred with the indigenous, it is almost safe to say that Spain's entire empire would have grown considerably, because pure Spaniards, wherever they may be, are Spaniards, while the bastard, mestizo or mulatto is no longer Spanish, even though they may live in Spain. For me, only he who thinks, feels and loves in Spanish is a Spaniard, never he who was born in Spain but does not have this in their blood, nor the Spanish soul in their spirit (Bañuelos, 1938b, p. 51).

Concerned with what he referred to as "impurities of race", his racist discourse led to the discrediting of races deemed inferior. Thus, he pointed out that he felt "profound sorrow" when contemplating exotic peoples who leave a stain on my race", confessing that he experienced "noble and laudable repugnance towards mixing with inferior humanity" (Bañuelos, 1938b, p. 95). This is some- 
thing he insisted on in 1941 when proclaiming that "the Spanish people has been tarnished and bastardized for many years now; and continues crossbreeding with inferior races" (Bañuelos, 1941a, p 60). Such was his rejection of racial mix that he ended up stating:

Insofar as it affects me personally, I would not like to have a black or yellow grandmother in the slightest, and I would be far happier knowing they were fair-haired or light brown [morenas claras], beautiful, honest and hard-working. No question about it" (Bañuelos, 1938b, p. 52).

The virulence of his arguments was also directed towards defenders of crossbreeding and Hispanidad. To this end, he maintained that his stance was not a materialistic one "in the way that those pseudo-intellectual Spaniards think, showing their sanctimoniousness, ignorance and supine laziness", but rather, "considerably more spiritual, because it contains far more truth" (Bañuelos, 1938b, p. 51). The defense of crossbreeding, the acceptance of "women of all races, and on the first day or within just a few minutes" of the first encounter was, in his view, "materialism. And a very coarse and filthy form at that! But it is not materialism to recommend continence and chastity and procreate solely with a physically and morally worthy female" (1938b, pp. 51-52).

Safeguarding racial purity should be the aim of the "racist doctrine" which, if understood properly, meant "the doctrine of mankind's moral uplift", whereas "unashamed racial promiscuity" represented "materialistic filth" (Bañuelos, 1938b, p. 52). This was a declaration that came into open conflict with Vallejo Nágera, who asserted that the future racial policy of the "New State" did not need to be racist. That same year, he recalled that "when referring to the Hispanic race we have avoided (...) the anthropological concept". In its place, he advocated the "mix of races that inhabit Spanish territory, and also South America, where our race predominates". The absence of racial prejudice - he went on-had led to "the splendid outcome of incorporating conquered nations into our civilization and also our conquistadors" (Vallejo Nágera, 1938b, p. 15). The Hispanic race was therefore not characterized by "anthropometric rates, but rather, by biopsychic ones" (1938b, p.17). By focusing his discourse on biopsychological features, Vallejo referred to spiritual aspects of the Spanish race that were in fact those referring to Hispanidad. Their loss was the cause of its decline and also that of Spain. Recovering the "racial psychological features of the seventeenth century" was the mission the "New State" needed to embark on as a basis for its racial policy. His radical environmentalism enabled him to properly link the spiritualism of Hispanidad with Biology, and to deny the leading role played by biological inheritance, arguing that its laws were not infallible (Vallejo Nágera, 1937, pp. 40-43). The consequences of this reasoning proved to be the differentiation between geneticist racial policies and behaviorist ones. The former, which focused on "selecting good-quality biotopes" and the segregation "of biological inferiors" was a mistake, as inheritance laws were not always adhered to. The root cause of the decline in race lay in the environment, which is why the racial policy to be pursued needed to be behaviorist (Vallejo Nágera, 1938b, p. 7-8). In view of these arguments, Bañuelos (1938b, p. 52) retorted that he found it "genuinely curious" that "the theory and science of inheritance would be accepted when referring to the animals and plants (...) but that it would be rejected when applied to man".

\section{PATRIOTISM, INTERNATIONALISM, ANTISEM- ITISM AND ANTIGYPSYISM}

In Revoluciones políticas y selección humana, ('Political revolutions and human selection'), the second volume of Problemas de mi tiempo y de mi patria, Bañuelos covered relationships between race, patriotism and internationalism. Along the same lines as the falangists who strongly criticized "vane, conformist, superficial (...), commemorative and historicist" patriotism (Saz Campos, 2003 , p. 244), he attacked passive, ineffective patriots who limited their patriotism "to showing off a button, or a small ribbon bearing national colors", to boasting "vociferously about their love of Spain" and, in many cases, to living from public office (Bañuelos, 1937a, p. 13). However, our doctor went beyond the falangist framework by delving into racial anthropology as an explanatory tool. Passive patriots would share certain "somatic typological characters" common to "certain racial groups or subgroups" (Bañuelos, 1937a, p. 14). Conversely, there were active, effective patriots, silent workers with racial features that came to the surface at historic crossroads such as the "Uprising" of $18^{\text {th }}$ July. He corroborated this extreme view with data pertaining to an alleged study by Vicente Baena and Jesús Fernández Cabeza into blood groups of "militia volunteers" that emerged in Valladolid at the start of the Spanish Civil War, which demonstrated that "European uniformity and a large contingent of Nordic blood" predominated among the first thousand. According to our doctor, this enabled one to understand how political ideas and sentiments were distributed across the different racial groups, and "how closely linked these ideas and sentiments are to racial personality" (Bañuelos, 1937a, pp. 56-57).

The other side of the coin to patriotism was internationalism, which was a source of endless evil and could be broken down into two tendencies: one unconscious insofar as he who pursued it was unaware of what they were, and another practiced while being aware of doing so. Unconsciousness internationalism involved the practice of racial mix since time immemorial with the consequent "multiplication and increase in inferior races and racial subgroups" (Bañuelos, 1937a, p. 27). One example of this was wthat happened by the Spanish conquistadors in the Americas when they crossed "their blood with native Indians in a carefree manner" (1937a, p. 24). To preserve racial purity and cleansing of blood or its improvement", he proposed a form of internationalism between "races similar to our own or those with greater content 
of superior race". Convinced that to a large extent there was "a grand racial family" in Europe with greater Nordic or Mediterranean Eurasian blood content, he proposed a form of internationalism that would be, according to zones, "limited to the true Europe, excluding Russia and some Polish and Romanian territories" (1937a, p. 26). For Bañuelos, Jews and gypsies personified the evil of internationalism. Although his antisemitism and antigypsyism were greatly influenced by Aryan racism, the fact is that both of thought were very widespread within the far-right sphere of activity. The difficulty in clearly defining and characterizing a Spanish race and the strong mark of Catholicism on reactionary thought were elements that carried weight in the detachment from and criticism of the racial conceptions of Nazism, and also helped to build another type of racism linked to the idea of Hispanidad. Yet there were fewer precautions taken regarding the Jewish and gypsy question.

Spanish antisemitism was mainly Catholic in nature. The fact of not sharing religion prevented Jews from being incorporated into Hispanidad and paved the way for their exclusion and racialization but, above all, from building an alter ego from it. As Álvarez Chillida (2002) points out, antisemitism flowed freely among far-right thinkers. Maeztu (1934, p. 205) clearly stated that "the Spanish character has been shaped via a multi-secular struggle against the Moors and Jews". These last-mentioned also emerged as the otherness necessary to build and reaffirm Catholicism and Hispanidad:

Our sense of Catholicity, of universality, was forged in response to the Jews, who are the most exclusive people on earth. The main concern of the faith of Israel is to maintain purity in terms of race. It is not true to say that Jews first and foremost constitute a religious community. They are a race. They believe in their own blood and in no other. They are the purest race in the world, because they have avoided mixing with others since the time of Ezra (Maeztu, 1934, pp. 206-207).

The definitive proof that they were a race rather than a religion, Mazetu went on (1934, p. 207), was that "A Jew remains a Jew when they abjure their faith", adding that "this compelled us to found the Inquisition". Neither did Giménez Caballero (1933, p. 149) remain on the sidelines when he pointed out that, following mass conversions by Jews, "all violence directed at them by Christians was justified" because "the Jew remained a Jew even beneath the Christian habit". And nor were those such as Vallejo Nágera atributed an insidious capacity to them to erase their "anthropological racial features, distinctive habits and none-to-clean ways" after they were expelled, subtly camouflaging themselves among the population in order to disseminate impiety, rationalism, materialism and Marxism (Vallejo Nágera, 1938a, p. 97).

Within this superficially described context, "suggestions of Aryan racism" as referred to by Álvarez Chillida (2002, p. 372), were greatly present in the milieu of the time.
Along these lines, Bañuelos appeared openly antisemitic, albeit in a different, contradictory way. In 1937, he maintained that the Jews "constituted the "typical racial group without fatherland" (Bañuelos, 1937a, p. 28), forming part of what he referred to as "intellectual internationalism". To this danger were added attempts to "always preserve the purity of their blood" by marrying each other although they were not opposed to "procreating with other races outside of wedlock" or entering into marriages of economic convenience (1937a, p. 28). Plenty of reference was also made to the secular cliché about their parasitism and recourse to Hitler as a source of authority: "Wherever they live, irrespective of the activities they undertake, they always do so as parasites, as Hitler justifiably stated, as the country's key problems as well as military service tend to be shunned using all the tricks in the book" (Bañuelos, 1937a, p. 29).

Parasitic ways of life enabled them to appropriate and rise to important positions and justify it " on the words pacifism, internationalism, humanitarianism, brotherhood and human fraternity, not to mention freedom above all - of conscience" (Bañuelos, 1937a, p. 30). This strategy was copied by other non-Jewish internationalists, leading to the ruin of other races and of civilization.

However, in 1941 he distanced himself from the usual clichés directed at Jews by denying they were a race or religion: "The Jewish people is not a race or a nation, and nor is it a racial mix, as (...) it is very difficult to find a psychological or racial resemblance among the distinct groups of Jews in the world" (Bañuelos, 1941b, p. 117).

Nonetheless, his message was a contradictory one. On few pages was he able to point out that Jews did not "all belong to a single race", that they were "racially speaking a racial hotchpotch" (Bañuelos, 1941b, p. 119) or claim that marriages between them facilitated: "the styling of a race that is accentuated by the fact that the Jew has practiced incest for a long time, which has greatly contributed towards the creation of a characteristic body and mental typology that makes the Jew unmistakable to many" (1941b, p. 121).

Descriptions of their physical features formed a large part of his argument. Thus, he considered them to be of "relatively small" stature, with long trunk and short legs, tending towards obesity and with a narrow thoracic cavity, short cranium, exaggerated lips, thickened eyelids, large nose and a pointed, forward-facing chin, etc. (Bañuelos, 1941b, pp.124-126). The clichés were repeated when referring to their psychological features: parasitism, seeking to turn things to their own advantage, intelligence in becoming involved in "finance, banking, literature and the press" and an ability to create and run international organizations, as well as an obsession with philosophical speculation (1941b, p. 127).

Also considering them to be a Pre-Asian race similar to the Phoenicians, Bañuelos stated that they had historically been the cause of "very serious political and social unrest on the Iberian Peninsula", pointing to their decisive role: 
In creating and provoking the Spanish inner catastrophe whereby most Catalan, separatist and left-wing leaders may be considered pre-Asian, starting with Companys (the Catalan President at the time), and also in the Vascongadas (Basque provinces), where Jews and semi-Jews, shipowners and bankers of Pre-Asian origin have cultivated and subsidized separatism and Basque leftism. Being close to descendants of converted Jews who attended the constituent assemblies and successive Republican assemblies, they would plot and plan the ruin of Spain, against which those regions that contained the largest amount of Nordic and Dalic blood in the whole of Spain turned" (Bañuelos, 1941b, p. 113).

The case of gypsies was different as they were mainly Catholics. Their exclusion from the Hispanidad racial project was more related to prejudices dating back centuries and because they emerged as "the only visible minority considered to be a different racial group" (Rothea, 2007). According to this author, the Francoist regime "was unable to disregard a racist depiction of gypsies as simply 'otherness', whereby full advantage was taken of their use as a "social counter-example' and internal social adversary for the regime's political purposes. The outcome was the historical continuation of gypsies' criminalization and racist essentialization. In 1937, Bañuelos limited himself to branding them as internationalists, semi-nomads, wanderers and of being a very prolific yet inoffensive and romantic race. However, in 1941 his racial discourse toughened when he clearly set out their supposed physical differences and differences in origin from the superior races that inhabited Europe and Spain. Firstly, he considered them to be a mix of Oriental and Pre-Asian race (Bañuelos, 1941b, p. 143) with a series of clearly defined features which ensured "that even the most slow-witted in matters of racial typology" would be able to distinguish "the gypsy from other racial types". Even wealthy and fully integrated gypsies were easily identifiable by their typology (Bañuelos, 1941b, p. 142). Totally unlike Europe where gypsies "act (...) as a completely alien and parasitic race", in Spain they had become assimilated and led their lives usually devoted to "small-scale industries or small business", or as artists or bullfighters". The real danger to the racial decline of Spain was represented by "the parasitic core" who belonged "to tribes arriving late to our nation". The solution he proposed was to "seal the country's borders to this immigration of inferior humanity", thus ruling out their assimilation. Sending them overseas or to Spanish colonies was one option that could be considered (Bañuelos, 1941, p. 145).

\section{REMEDIES: EMPIRE, HUMAN SELECTION, RA- CIAL HYGIENE, EUGENICS}

Bañuelos's analysis of the situation in Spain was a pessimistic one. His criticism, which was profoundly anti-democratic, focused on the lack of racial policy and the havoc wreaked by the rise of the least gifted at the country's decision-making core. He also shared the angst and anxiety about racial decline and the Palingenetic myth so loved by the far right, which considered the uprising of $18^{\text {th }}$ July and the Spanish Civil War as the turning point that would pave the way for Spain's recovery. Throughout his work he referred, in a none-too-systematized way, to two courses of action required to recover the biological and racial grandeur of the Spanish people: the creation of an empire and the selection of the most gifted.

As for the former, it advocated an overseas national idea embodied in the idea of empire. The importance that overseas imperial missions might have over national conscience of the Spanish people had been proposed by Ortega in España invertebradas (Invertebrate Spain) in 1922. Although these stances did not fall within the farright universe, they were reinterpreted by fascists and, to a lesser extent, by traditionalists who used them for their own ends during the 1930s and 1940s (Saez Campo, 2003). The idea of empire was a constant about which fascist ideologues, representatives of Acción Española and traditionalists wrote a great deal; yet it was also an area of conflict between both sectors who bestowed different meanings on it. Thus, whereas the latter tended to give it a spiritual explanation, the former generally advocated giving it a real form (Saz Campos, 2003). Bañuelos would have fitted into the latter group, albeit always including the major biologistic component that characterized his thought. He hence maintained that a people could not progress without having "an overseas national ideal of conquest, of command, of stateliness" (Bañuelos, 1938b, p. 47). Yet this could not be confined to a vague, spiritual idea. In this regard, he strongly criticized sectors of "nationalist Spain" that limited the significance of empire "to an alleged inner grandeur" and "a hypothetical influence abroad", recalling that the "notion of empire is based on overseas dominion and the constant expansion of such dominion" (Bañuelos, 1937c, p. 114). The attitude of those defenders of the spiritual conception of empire was counterproductive in terms of race:

\footnotetext{
Withdrawing oneself within one's borders without hunger for overseas conquests and dreaming of empire is both an antithesis and a contradiction, which is only possible because those who say and write such things have failed to immerse themselves in the true biological meaning of empire (1937c, p. 114).
}

However, war and conquests needed to be pursued owing to "supreme interest in the nation and race" if the aim was to guarantee "biological meaning" to "national and international policy" (Bañuelos, 1938b, p. 48). The Social Darwinism substratum of his arguments was very clear when he justified the fact that peoples with superior culture and civilization needed to dominate and wield power over inferiors. In this regard, militarism was essential, although technique and science no less so, as fundamental weapons of overseas expansion (1938b, pp. 53-54). Cultivating both was in turn essential if the aim was to ensure a realistic, modern imperial policy. The natural place for Spanish imperial expansion was, in his view, north Africa, 
as he expressed in several parts of his work. Without any restraint he defended an African empire that would cover "the whole of Morocco and part of Algeria" as, conversely, Spain's culture and independence would always be "threatened with death" owing to the existence of a potential risk of the (Iberian) Peninsula being invaded (1938b, p. 54). Moreover-and at this point his arguments took a surprising turn-common racial components existed in both Morocco and Algeria that facilitated "the crossing of blood" as, unlike the conquest of the Americas, "men would not end up being crossbred who would no longer feel and think like the most perfect ancestral race" (1938b, p. 54).

The second key point in the recovery of racial vigor was the selection of the most gifted. His discourse retained a racist, biologistic tone and introduced elements of eugenics and racial hygiene. However, unlike Vallejo Nágera and other Catholic eugenicists, he put forward vague proposals that failed to give rise to a specific program for political action, despite his reiterated positive allusions to the racial policies pursued by National Socialism. Along the same lines as many other eugenic doctors and psychiatrists, the idea behind his thought was that a reverse selection was taking place that favored the least gifted over the most gifted. The dramatic consequences of this were the destruction of "a civilization and culture" and the tendency to create "a primitive type of society like that of the caveman" (Bañuelos, 1936, pp. 121-122). The cause of that unnatural selection had historic roots and had been upheld by politicians' careless disregard for the "study of political and hygiene-based policy towards races and peoples" (Bañuelos, 1938a, p. 122). The type of democracy and egalitarian policies pursued since the $19^{\text {th }}$ century had a bearing on the problem and created a favorable atmosphere in fostering reproduction of the least gifted and their rise to political decision-making positions. In this regard, a debate at the heart of Spanish Medicine existed that revolved around whether the quality and quantity of the Spanish population should be fostered. The work carried out on racial hygiene and eugenics was also influenced by this question and by the apparent tension arising from an admiration for the racial policies being pursued by National Socialism and submissiveness before the Catholic doctrine (Polo, 2006; Campos, 2016, 2018). Most of them - greatly marked by Catholicism and the demographic policy pursued by the regime to increase the birth rate (Bernabeu, 2011)—subordinated quantity to quality, without renouncing the latter, arguing like López Ibor that "the quantitative increase is needed to ensure qualitative improvement” (López Ibor, 1943, p. 43).

However, Bañuelos (1936, p. 123) thought "humanity is not worth more in terms of quantity than quality". Although he did not openly defend sterilization of those he considered "infrahuman", he nonetheless advocated putting a stop to laws that favored their reproduction, although he failed to explain clearly how to do this (Bañuelos, 1938a, pp. 142-143). Despite his lengthy arguments about the races that inhabited Spain and the racial decline that democracy had entailed by favoring governance by the least qualified, this did not take the form of a detailed eugenic project. His great biologistic commitment was confined to requesting "a law protecting the best qualified, which would enable them to start reproducing (...) between the ages of 25 and 28 " that would limit those "that were clearly poorly gifted" to not having more than two or three children (Bañuelos, 1936, p. 152). This measure was justified by the conviction-much in vogue in eugenic thought - that the high classes and most educated strata in society tended to reproduce less or to do so at a later age, whereas the popular classes and the least gifted were especially promiscuous. In this regard, he distanced himself from the Catholic doctrine that was opposed to putting obstacles in the way of human reproduction. These measures also needed to be accompanied by racial policies that favored environmental improvements, such as the cultural uplift of the people or improvement in their diet, or that would prevent crossbreeding with inferior races. In reality, his project had a bearing on the need to introduce racial hygiene in order to stamp out any features of decline that democracy had brought to the country in the form of governance by the mediocre.

\section{EPILOGUE}

In May 1941, the anthropologist José Pérez de Barradas, the new director of the Bernardino de Sahagún Institute of Anthropology and Ethnology (IBS) attached to the CSIC, noted two comments in his diary addressed to Bañuelos and his book Antropología actual de los españoles and to Vallejo Nágera and his work Política Racial del Nuevo Estado ('Racial policy of the New State'). Regarding the former, he pointed out that it was "an indecorous copy of German racist things". As for the latter, he had some very tough words to say: "What a stupid book, that Racial Policy of the New State by Vallejo Nájera! This neurologist is an idiot, even though he's very close to Franco". 6

These value judgements emanating from a personal diary by one of the bigwigs in the Anthropology of the "New State" shows the complexity of the framework of racial thought during the early years of Francoism, appropriate to the internal tension existing within the regime among openly fascist, traditionalist but also opportunist sectors. In 1942, Pérez de Barradas, as Sánchez Gómez has stated (1992: 33), presented a project involving regulation of the IBS in which he put forward the idea of cultivating Anthropobiology with a view to improving race. The project failed to gain much traction, as the Axis defeat in 1945 meant the definitive hegemony of National Catholicism over fascist sectors sectors on an internal level (Sanz Campos, 2013). However, as has been pointed out, Bañuelos ran a center in Valladolid that had been associated with the IBS since 1944. In accordance with the annual reports issued by the CSIC, there was not much activity in this section, although its original intention was to undertake "the anthropological study of Old Castile, Leon, Asturias and Galicia"'. In the report for the years 1946-1947, it was stated that Bañuelos had "terminated 
his study of Celticism in Spain", and that scholarship holders were working on racial questions such as blood groups, the lower jaw in the different races and handprint features in terms of racial types and pathological states ${ }^{8}$. In the following reports appeared small notes referring to the continuation of this work without the results being published.It is likely that Fernández Cabezas, the IBS secretary at the time and a disciple of Bañuelos, played a major role as an intermediary in setting up the Valladolid delegation at a time when Pérez de Barradas needed allies to offset the increasing power of the Barcelona group with Alcobé at the helm. Nonetheless, it would seem that Bañuelos's work did not have any special relevance in the 1940s. The turn taken by events in World War II in 1943 and the definitive defeat of Germany two years later resulted in growing support for National Catholicism, and the regime was compelled to update its policy in which sympathy towards Nazism would be excluded. Beyond the mentions made by Vallejo Nágera about Bañuelos's work in 1947, his racial work would have no impact on the context of Medicine and Anthropology.

However, following Bañuelos's death, the doctor Justo Garate, who was exiled in Argentina, published a fierce, sharp and long article in the Boletín del Instituto Americano de Estudios Vascos (Journal of the American Institute of Basque Studies) ('Fallacies of Support for Anthropology') in which he criticized in great detail and highlighted the limited scientific validity and the unmethodical discourse regarding the racial ideas expounded in Antropología actual de los Españoles. He justified the reasons for such late-in-the-day criticism by stating that "nobody, as far as I am aware, has protested in Spain against that stupid book by Bañuelos" (Garate, 1956, p. 26) which, according to him, was still being read and that there were "millions of people in Spain" who "think the same as him" (Garate, 1956, p. 25). In a very ironic passage of his long article, Garate commented that at the end of the book were listed " 6 works of his about Biological Sociology, and I think I can guess what they'll be about. I'll study Czech before I read these works" (Garate, 1956, p.27).

Beyond this outburst by Garate, what would appear necessary despite the low quality of Bañuelos's biocratic work is to analyze it and link it to the Francoist racial universe in order to enrich our view about it and study his knowledge in greater depth. Otherwise, we run the risk of continuing to conceal, whitewash or subsume his political thought under the smokescreen of the openly scientific side of his work.

\section{ACKNOWLEDGEMENTS}

This article has been written within the framework of the research Project "De la Higiene mental a la postpsiquiatría: la construcción de la salud mental colectiva en la España del siglo XX”. (MINCINN/FEDER) RTI2018-098006-B-I00.

\section{NOTES}

1 Memoria de la Secretaría General. Año 1945, Madrid, Consejo Superior de Investigaciones Científicas, 1946, p. 236 y Memoria de la Secretaría General. Año 1946-1947, Madrid, Consejo Superior de Investigaciones Científicas, 1948, p. 499.

2 Biocratic derives from the French term biocratique, which refers to a political system based on eugenics and natural selection.

3 Mentions and use of Nazi scientific work as a source of authority are made throughout the 6 volumes of Problemas de mi tiempo $y$ de mi patria and Antropología actual de los españoles. The information provided about the authors is confined to their surnames. We have reconstructed their full names and their area of specialization thanks to the works by Massin (2005); Richards (1997), in particular the sixth chapter, and Hutton (2005).

4 The word dálica in Spanish referred at the time to a Nordic subrace of peoples who largely inhabited areas around the Baltic.

5 Similarly, preasiática was also used in racial discourse at the time to refer to peoples inhabiting the Caucasus region and parts of northern Turkey, although it was also sometimes used to refer to Phoenicians and Jewish people, and even ancient races such as the Basques.

6 Las citas pertenecen al diario de Pérez de Barradas y las recoge Sánchez Gómez (2008, pp. 408 y 430).

7 Memoria de la Secretaria General, año 1945, Madrid, 1946, p. 236.

8 Memoria de la Secretaria General, año 1946-1948, p. 287.

\section{REFERENCES}

Álvarez, R. (2007) "Eugenesia y franquismo: una primera aproximación". In: G. Vallejo and M. Miranda, eds., Políticas del cuerpo: estrategias modernas de normalización del individuo y la sociedad. Buenos Aires: Siglo XXI, pp. 143-168.

Álvarez Chillida, G. (2002) El antisemitismo en España: la imagen del judio (1812-2002). Madrid: Marcial Pons.

Álvarez Peláez, R. (1998) "Eugenesia y fascismo en la España de los años treinta". In: R. Huertas y C. Ortiz, eds., Fascismo. Aranjuez: Doce Calles, pp. 77-95.

Bandrés, J. and Llavona, R. (1997) "Psychology in Franco's concentration camps". Psychology in Spain, 1(1), pp. 3-9.

Bañuelos, M. (1936) Problemas de mi tiempo y de mi patria. Volumen I. Cuestiones político biológicas. Valladolid: Imprenta Castellana.

Bañuelos, M. (1937a) Problemas de mi tiempo y de mi patria. Volumen II. Revoluciones políticas y selección humana. Valladolid: Librería Santarén.

Bañuelos, M. (1937b) Problemas de mi tiempo y de mi patria. Volumen III. Universidad, prestigio y grandeza nacional. Valladolid: Librería Santarén.

Bañuelos, M. (1937c) Problemas de mi tiempo y de mi patria. Volumen IV. Mentalidad y progreso humano. Valladolid: Librería Santarén.

Bañuelos, M. (1938a) Problemas de mi tiempo y de mi patria. Volumen V. Temas de crítica diaria. Valladolid: Librería Santarén.

Bañuelos, M. (1938b) Problemas de mi tiempo y de mi patria. Volumen VI. Los grandes errores nacionales. Valladolid: Librería Santarén.

Bañuelos, M. (1941a) Temas y meditaciones breves. Valladolid: Librería Santarén.

Bañuelos, M. (1941b) Antropología actual de los españoles. Barcelona: Editorial Científico Médica.

Bañuelos, M. (2007) Antropología de los españoles. Madrid: Editorial Retorno.

Blanco Rodríguez, J. A. (1997) "El regionalismo en Castilla y León en años Treinta", In: J. A. Blanco Rodríguez, ed., Problemas de la Castilla Contemporánea. Zamora: UNED, pp. 91-110.

Bernabeu-Mestre, J. (2011) "Madres y enfermeras. Demografía y salud en la política poblacionista del primer franquismo, 19391950", Revista de Demografía Histórica, 20 (1), pp. 123-143. 
Campos, R. (2007) "Biocracia versus democracia. Los proyectos biocráticos de E. Toulouse, A. Carrel y A. Vallejo Nágera”, In: M. Miranda y G. Vallejo, dirs., Ciencia y control social: biopolíticas y tecnologías del cuerpo en la modernidad. Buenos Aires: Siglo XXI, pp. 199-235.

Campos, R. (2016) "Autoritarismo y eugenesia punitiva: higiene racial y nacionalcatolicismo en el franquismo, 1936-1945", História, Ciências, Saúde - Manguinhos, v.23, suplemento dezembre, pp. 131-147. doi: https://doi.org/10.1590/s010459702016000500008

Campos, R. (2018) "Entre la ciencia y la doctrina católica: Eugenesia, matrimonio y sexualidad en el primer franquismo", Cuadernos de Historia Contemporánea, 40, pp. 51-71. doi: https:/doi. org/10.5209/CHCO.60322

Campos, R. and Novella, E. (2017) "La higiene mental durante el primer franquismo. De la higiene racial a la prevención de la enfermedad mental (1939-1960)", Dynamis 2017; 37 (1), pp. 6587. doi: https://doi.org/10.4321/S0211-95362017000100004

Carrel, A. (1935) L'homme, cet inconnu. Paris: Librairie Plon.

Casco Solís, J. (1999) "Psiquiatría y franquismo. Periodo de institucionalización (1946-1960)”. In: F. Fuentenebro, G. E. Berrios, I. Romero and R. Huertas, eds., Psiquiatría y cultura en España en un Tiempo de Silencio. Madrid: Necodisne, pp. 85-128.

Cayuela, S. (2014) Por la grandeza de la patria. La biopolítica en la España de Franco. Madrid: Fondo de Cultura Económica.

Cenarro, A. (2006) La sonrisa de Falange: auxilio social en la guerra civil y en la posguerra. Barcelona: Crítica. 2006.

Díaz-Andreu, M. (2002) Historia de la Arqueología. Estudios. Madrid: Ediciones Clásicas.

Drouard, A. (1995) Alexis Carrel De la mémoire a l'histoire. Paris: L'Harmattan.

Elorza, A. (1984) La razón y la sombra. Una lectura política de Ortega y Gasset. Barcelona: Editorial Anagrama.

Gallego, F. (2014) El evangelio fascista. La formación de la cultura política del franquismo (1930-1950). Barcelona: Crítica.

Garate, J. (1956) "Falacias de la antropología partidaria", Boletín del Instituto Americano de Estudios Vascos 7 (24), pp. 24-31.

Giménez Caballero, E. (1932) Genio de España. Exaltaciones a una resurrección nacional y del mundo. Madrid: Ediciones de La Gaceta Literaria.

Giménez Caballero, E. (1933), La nueva Catolicidad. Teoría sobre el fascismo en Europa: España. Madrid: Ediciones de La Gaceta Literaria.

Goode, J. (2009) Impurity of Blood: Defining Race in Spain, 18701930. Baton Rouge: Louisiana State University.

Granda Juesas, J. M. (1987) Don Misael Bañuelos, medicina, antropología y sociedad. Valladolid: Universidad de Valladolid.

Guinaldo Martín, V. (2015) Identidad y territorio de Castilla y León en la opinión pública de Valladolid: 1858-1939: génesis y configuración del regionalismo castellano. Tesis doctoral. Universidad de Valladolid. Vol. II. Disponible en: http://uvadoc.uva.es/ handle/10324/16801

Huertas, R. (1996) "La Psico-Biología del Marxismo como categoría antropológica en el ideario fascista español”, Llul, 19 (36), pp. 111-130.

Huteau, M. (2002) Psychologie, psychiatrie et société sous la Troisième République. La biocratie d'Edouard Toulouse (18651947). Paris: L'Harmattan.

Hutton, Ch. (2005) Race and the Third Reich: Linguistics, Racial Anthropology and Genetics in the dialectic of Volk. Oxford: Polity press.

López Ibor, J. J. (1938) Discurso a los universitarios españoles. Santander: Cultura Española.

López Ibor, J. J. (1942) Neurosis de Guerra. Psicología de Guerra. Barcelona-Madrid: Editorial Científico Médica.

López Ibor, J. J. (1943) "Factores genéticos en una política de población”. SER. Revista Médico-Social. Delegación Nacional de Sanidad de FET y de las JONS. 6, pp. 37-44.

López Sáez, I. (1983) Biografía de Don Misael Bañuelos. Burgos: Publicaciones de la Exma. Diputación Provincial de Burgos.
Maeztu, R. (1934) Defensa de la Hispanidad. Madrid: Gráfica Universal.

Marco Merenciano, F. (1958 [1942]) "Nuevas Orientaciones sobre Higiene Mental" In: F. Marco Merenciano, Ensayos Médicos y Literarios. Antología. Madrid: Ediciones Cultura Hispánica.

Massin, B. (2005) "Apprendre à classer et à sélectionner : L'enseignement de l'eugénisme, de l'hygiène raciale et de la raciologie dans les universités allemandes (1930-1945)". Revue d'Histoire de la Shoah, 183(2), pp. 265-388. doi: https://doi.org/10.3917/ rhsho.183.0265.

Mederos Martín, A. (2003-2004) "Julio Martínez Santa-Olalla y la interpretación aria de la Prehistoria de España (1939-1945)". Boletín del Seminario de Estudios de Arte y Arqueología: BSAA, 69-70, pp. 13-56.

Miranda, M. (2003) "La antorcha de Cupido: eugenesia, biotipología y eugamia en Argentina, 1930-1970”, Asclepio, 55 (2), pp. 231-255. doi: https://doi.org/10.3989/asclepio.2003.v55.i2.111

Morales Moya, A y Esteban de Vega, M. (2005) ¿Alma de España?: Castilla en las interpretaciones del pasado español. Madrid: Marcial Pons.

Morodo, R. (1985) Los orígenes ideológicos del franquismo: Acción Española. Madrid: Alianza Editorial.

Ortega y Gasset, J. (1922) España invertebrada. Bosquejo de algunos pensamientos históricos. Madrid: Calpe.

Palacios Arroyo, L. F. (2015) Autonomismo inducido. Dialéctica nacionalista en el período comprendido entre el advenimiento de la II República y la aprobación del Estatuto de Autonomía de Cataluña. Tesis Doctoral. UNED, Madrid.

Polo Blanco, A. (2006): Gobierno de las poblaciones en el primer franquismo (1939-1945). Cádiz: Universidad de Cádiz.

Regianni, A. H. (2006), God's Eugenicist: Alexis Carrel and the Sociobiology of Decline. New York: Berghahn Books.

Richards, R. (1997) Race, Racism and Psychology: Towards a Reflexive History. London-New York: Routledge.

Rothea, X. (2007) "Hygiénisme racial et kriminalbiologie : L'influence nazie dans l'appréhension des gitans par les autorités franquistes en Espagne". Études Tsiganes, 30(2), pp. 26-51. doi: https://doi.org/10.3917/tsig.030.0026.

Rothea, X. (2014) “Construcción y uso social de la representación de los gitanos por el poder franquista. 1936-1975". Revista Andaluza de Antropología, 7, pp. 7-22. doi: https://doi.org/10.12795/ RAA.2014.i07.01

Sánchez Gómez, L. A. (1992) "La antropología al servicio del Estado. El Instituto 'Bernardino de Sahagún' de CSIC (19411970)". Revista de dialectología y tradiciones populares, 47, pp. $29-44$

Sánchez Gómez, L. A. (2008) "Antropologías para después de una guerra. Plenitud y declive de la obra antropológica de Pérez de Barradas (1939-1952)". In: Arqueología. América. Antropología. José Pérez de Barradas, 1897-1981. Madrid: Museo de los Orígenes, Ayuntamiento de Madrid, pp. 399-431

Saz Campos, I. (2003), España contra España. Los nacionalismos franquistas. Madrid: Marcial Pons Ediciones de Historia.

Saz Campos, I. (2013), Las caras del franquismo. Granada: Comares.

Selva, E. (2004) “Gecé y la 'vía estética' al fascismo en España”. In: F. Gallego y F. Morente, eds., Fascismo en España. Madrid: El Viejo Topo, pp. 69-108.

Stepan, N. L. (1991) The hour of eugenics: race, gender, and nation in Latin America. Ithaca: MCornell University Press.

Tomás Cardoso, R. P. (2015), El desarrollo de la Antropología Física española en el contexto de la Historia de la Antropología Física y las teorías bioantropológicas europeas y americanas: una historia de contactos, desarrollos paralelos y convergencias. Tesis presentada para acceder al Grado de Doctor dentro del Programa de Doctorado en Antropología Física. Madrid: UAM. Disponible en: https://repositorio.uam.es/ handle/10486/672395

Vallejo Nágera, A. (1937) Eugenesia de la hispanidad y regeneración de la raza. Burgos: Editorial Española. 
Vallejo Nágera, A. (1938a) Divagaciones intrascendentes. Valladolid: Talleres Tipográficos Cuesta.

Vallejo Nágera, A. (1938b) Política racial del nuevo Estado. San Sebastián: Editorial Española.

Vallejo Nágera, A. (1947) Biotipología. Valencia-Barcelona: Editorial Modesto Usón.

Vallejo, G. and Miranda, M. (2014), "Iglesia católica y eugenesia latina: un constructo teórico para el control social (Argentina, 1924-1958)", Asclepio, 66 (2), p055. doi: https://doi. org/10.3989/asclepio.2014.19
Vázquez García, F. and Moreno Mengíbar, A. (1997) Sexo y Razón. Una genealogía de la moral sexual en España (Siglos XVI-XX). Madrid: Akal.

Villacañas, J. L. (2000) Ramiro de Maeztu y el ideal de la burguesía en España. Madrid: Espasa.

Wulff, F. (2003) Las esencias patrias: historiografía e historia antigua en la construcción de la identidad española (siglos XVI$X X)$. Barcelona: Crítica. 